\title{
Occurrence period, severity and management of powdery mildew and rust in Jatropha curcas
}

\author{
Alexandre Dinnys Roese ${ }^{1 *}$, Walmes Marques Zeviani ${ }^{2}$, Harley Nonato de Oliveira ${ }^{1}$, Cesar José da Silva ${ }^{1}$
}

${ }^{1}$ Embrapa Agropecuária Oeste, Caixa Postal 449, 79804-970, Dourados, MS, Brasil. ${ }^{2}$ Universidade Federal do Paraná, Departamento de Estatística, Caixa Postal 19.081, 81531-990, Curitiba, PR, Brasil

Autor para correspondência. Alexandre Dinnys Roese (alexandre.roese@embrapa.br)

Data de chegada: 07/06/2017. Aceito para publicação em: 26/09/2017.

$10.1590 / 0100-5405 / 181088$

\section{ABSTRACT}

Roese, A.D.; Zeviani, W.M.; Oliveira, H.N.; Silva, C.J. Occurrence period, severity and management of powdery mildew and rust in Jatropha curcas. Summa Phytopathologica, v.44, n.3, p.274-277, 2018.

Jatropha curcas L. has been studied with the aim of attending the bioenergy demand in Brazil. In this study, the time of occurrence, the severity, and the control of powdery mildew and rust in a commercial crop were investigated. During the evaluation period, powdery mildew was first observed soon after the onset of the raining period in October. Rust was first observed in April. Metarhizium anisopliae, Azadirachta indica oil, J. curcas oil, and the fungicide triadimenol were efficient in controlling powdery mildew. None of these products nor potassium silicate did control rust.

Keywords: Oidium sp.; Phakopsora arthuriana; bioenergy; physic nut.

\section{RESUMO}

Roese, A.D.; Zeviani, W.M.; Oliveira, H.N.; Silva, C.J. Época de ocorrência, severidade e manejo de oídio e ferrugem em Jatropha curcas. Summa Phytopathologica, v.44, n.3, p.274-277, 2018.

Jatropha curcas L. tem sido estudada com o objetivo de atender a demanda por bioenergia no Brasil. Neste trabalho estudou-se a época de ocorrência, a severidade e o controle do oídio e da ferrugem numa lavoura comercial. Durante o período de avaliação, o oídio foi observado pela primeira vez logo após o início do período de chuvas em outubro. A ferrugem foi observada pela primeira vez em abril. Metarhizium anisopliae, óleo de Azadirachta indica, óleo de J. curcas e o fungicida triadimenol foram eficientes no controle do oídio. Nenhum desses produtos nem silicato de potássio controlaram a ferrugem.

Palavras-chave: Oidium sp.; Phakopsora arthuriana; bioenergia; pinhão-manso.

Jatropha curcas L. (Euphorbiaceae) has been of interest for biodiesel production in Brazil. Although this species was initially considered to present low incidence of diseases, recent studies have found the opposite (1). Diseases like rust caused by Phakopsora arthuriana Buriticá \& Hennen (4) and powdery mildew (PM) caused by Oidium sp. Sacc. (3) have been reported in J. curcas. The importance and the epidemiology of diseases affecting this host, as well as control forms, have not been studied yet. The aim of this study was to evaluate the occurrence of diseases affecting $J$. curcas and the efficiency of some natural and chemical products in their management.

Evaluations were carried out during 2011 and 2012 in a six-yearold commercial crop, in Dourados, Mato Grosso do Sul State, Brazil. The plantation was established with three meters between rows and two meters between plants in the row. Experimental design consisted of six treatments for disease control arranged in four blocks. Each plot consisted of six rows of six plants, from which ten leaves plus petiole from the four central plants were monthly evaluated. Treatments were: i) control with water alone; ii) potassium silicate $(168 \mathrm{~g} / \mathrm{L} \mathrm{Si}$ at $0.7 \%$ volume); iii) Metarhizium anisopliae ( $5 \times 10^{11}$ conidia $/ \mathrm{kg}$ at $\left.3 \mathrm{~kg} / \mathrm{ha} ; \mathrm{iv}\right)$ Azadirachta indica oil at $2.5 \%$ volume; v) Jatropha curcas oil at $1.5 \%$ volume; and vi) triadimenol (250 g a.i./L) + imidacloprid (175 g a.i./L). Treatments $i$ to $v$ were monthly sprayed on the plants at a volume of 400 $\mathrm{L} / \mathrm{ha}$, using a motorized costal sprayer and conical nozzle. Treatment vi was bimonthly sprayed on the naked soil under the canopy at a volume of $50 \mathrm{~mL}$ per plant, using a $\mathrm{CO}_{2}$ constant pressure sprayer and fan nozzle, according to the recommendation for coffee (Coffea sp.) in Brazil. Treatments were applied during the whole evaluation period and focused on disease and insect control.

PM was assessed in petioles and leaves, while rust was assessed only in leaves. For petioles, PM severity was determined based on the percentage of the total length of symptoms, always considering the most diseased face. Thus, five petioles showing different severities (including the minimum and the maximum observed severity) were collected from the control treatment at each evaluation time. These petioles had their percentage of length showing symptoms assessed with a ruler and were used as models in this assessment. The number of lesions per leaf determined PM incidence on the leaves. The estimated visual percentage of leaves showing symptoms, without a standard area diagram, determined rust severity. The area under the disease progress curve (AUDPC) was calculated for each disease. Grains were weekly collected and the yield of grains and oil was assessed at the end of the disease evaluations. Oil content was estimated according to Soxhlet method (9). Statistical analyses were performed using R software (7).

PM was observed at the beginning of refoliation in the spring, soon after the onset of the raining season, and persisted until the beginning of winter, when plants naturally lost their leaves (Figure 1). Pearson's 
correlation coefficient between the AUDPC for PM petiole severity and the number of leaf lesions was 0.41 , indicating a low correlation. Rust was observed six months after refoliation in autumn, persisting until natural defoliation (Figure 1).

Most treatments reduced PM. No treatment reduced rust severity (Figure 2). M. anisopliae, J. curcas oil, and triadimenol + imidacloprid reduced the yield of grains and oil; $A$. indica oil reduced oil production; potassium silicate did not control the diseases or enhanced oil production but improved the yield of grains (data not shown).

Results showed that PM in J. curcas is favored by the dry season, as observed for other hosts (5). P. arthuriana required some months of development in the host before causing disease, as observed for other rusts (2). This indicates that emphasis on PM control has to be at the beginning of refoliation and that rust occurs later than PM in the crop season. $J$. curcas tolerated the incidence and the severity of the diseases recorded in this study without yield losses, since the disease reduction promoted by the treatments did not increase the yield. However, the frequency of treatments applied in this study was arbitrarily determined and may not be suitable for rust and PM control in J. curcas.

M. anisopliae is recommended for insects and not for disease control but controlled PM in both petioles and leaves, as previously observed for PM in soybean (Glycine max L.) (8). A. indica oil has been used to control other pathogens, including biotrophs (6).

In conclusion, PM in $J$. curcas occurs in the spring, soon after refoliation, while rust occurs later, in the autumn. Both chemical and alternative control measures have the potential to face PM, although J. curcas tolerates the PM severities recorded in this study. Potassium silicate enhances the grain production of $J$. curcas.

A

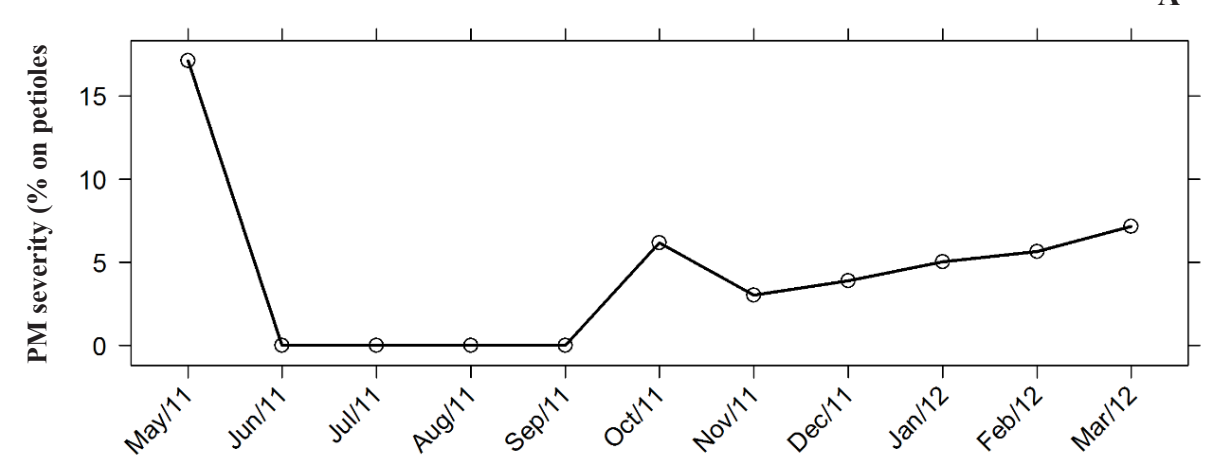

B

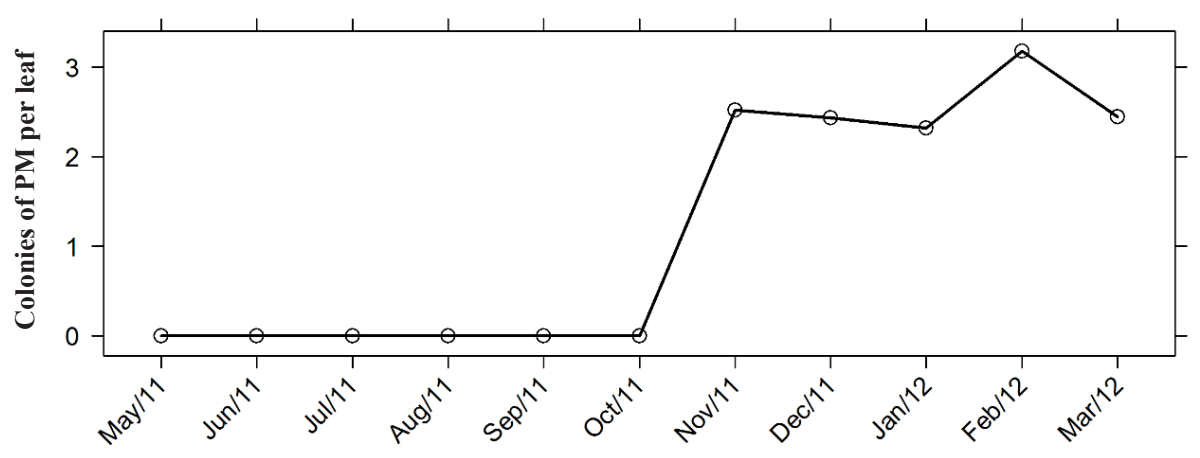

C

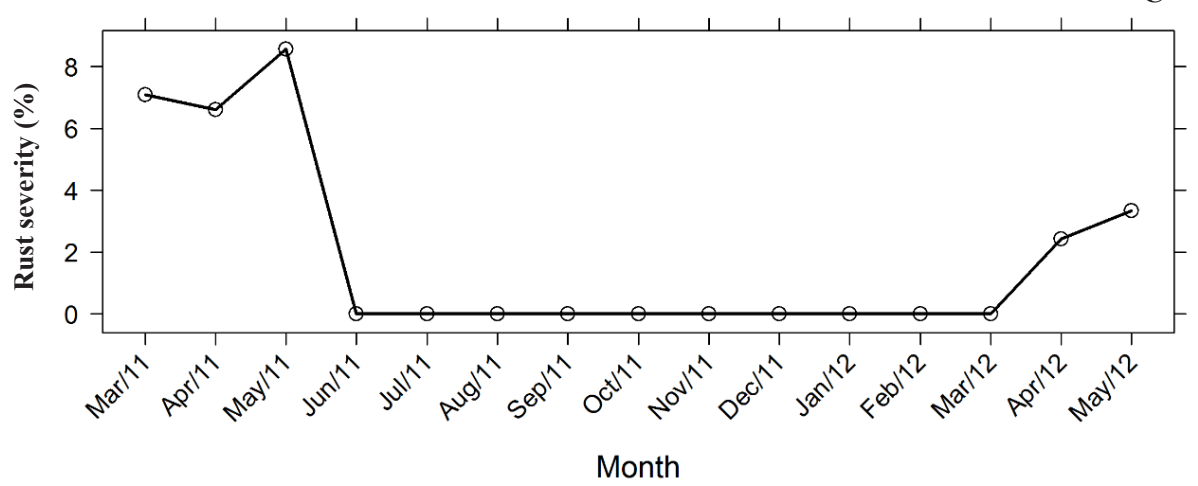

Figure 1. Powdery mildew (PM) severity on petioles (a); number of PM colonies on leaves (b); and rust severity on leaves (c) of Jatropha curcas along the months. Each point is the average of 240 leaves (6 treatments X 4 blocks X 10 leaves). PM on petioles was evaluated based on the percentage of the petiole extension with signs or symptoms. 

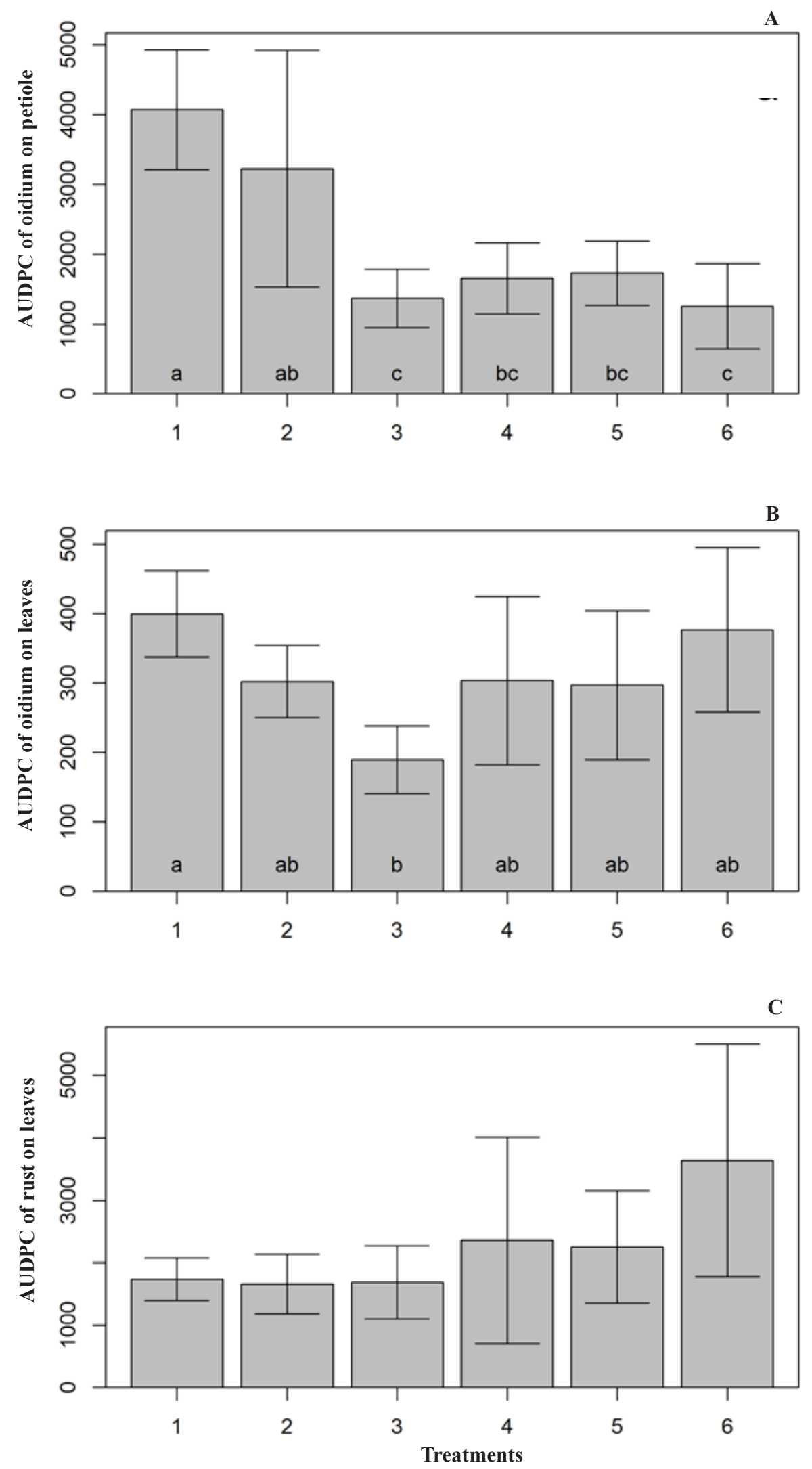

Figure 2. Area under the disease progress curve for powdery mildew (PM) severity on petioles (a); number of PM colonies on leaves (b); and rust severity on leaves (c) of Jatropha curcas under the treatments: 1) control, 2) potassium silicate, 3) Metarhizium anisopliae, 4) Azadirachta indica oil, 5) J. curcas oil, and 6) triadimenol + imidacloprid. Columns with the same letter are not different according to Tukey's test ( $\mathrm{p}=0.05)$. Bars show $95 \%$ confidence interval. 


\section{ACKNOWLEDGEMENTS}

We thank Ernst Ferter, owner of Paraíso Farm, where the experiments were carried out; "Fundação de Apoio ao Desenvolvimento do Ensino, Ciência e Tecnologia do Estado de Mato Grosso do Sul - FUNDECT" (Grant no. 0067/09), and "Financiadora de Estudos e Projetos - FINEP" (Agreement no. 01.10.0015.00), for financial support.

\section{REFERENCES}

1. Anitha, K.; Varaprasad, K.S. Jatropha pests and diseases: an overview. In: Carels, N.; Sujatha, M.; Bahadur, B. Jatropha, challenges for a new energy crop. New York, NY: Springer New York; 2012. p. 175-218. Available at: <http://link.springer.com/10.1007/978-1-4614-48068 10>. Accessed on: 22 May 2017.

2 .

Del Ponte, E. M.; Esker, P.D. Meteorological factors and Asian soybean rust epidemics - a systems approach and implications for risk assesment. Scientia Agricola, Piracicaba, v. 65, special issue, p. 88-97, 2008. Available at: <http://www.scielo.br/pdf/sa/v65nspe/a14v65nsp. pdf $>$. Accessed on: 28 Apr. 2017.

3. Dianese, A. de C.; Cargnin, A. Ocorrência de Oidium sp. em pinhão-manso (Jatropha curcas L.) em Planaltina, DF. In: Simpósio Nacional Cerrado, 9., 2008, Brasília. Anais. Brasília, DF: Embrapa Cerrados, 2008, p. 4.
4. Dianese, J.; Inacio, C.; Goulart, A. C.; Roese, A. D. First record of Jatropha rust (Phakopsora arthuriana) in Central Brazil. Phytopathology, St. Paul, v. 99, n. 6 (Supplement), 2009. p. S28. (Abstract). Available at: <http://admin. apsnet.org/meetings/meetingarchives/2009Annual/Documents/2009Abstracts.pdf>. Accessed on: 28 Apr. 2017.

5. Glawe, D. A. The powdery mildews: A review of the world's most familiar (yet poorly known) plant pathogens. Annual Review of Phytopathology., Palo Alto, v. 46, n. 1, p. 27-51, 2008. Available at: $<$ http://www.annualreviews.org/doi/abs/10.1146/annurev.phyto.46.081407.104740>. Accessed on: 25 Jul. 2016.

6. Li, Y.; Mmbaga, M. T.; Windham, A. S.; Windham, M. T.; Trigiano, R. N. Powdery mildew of dogwoods: current status and future prospects. Plant Disease., St. Paul, v. 93, n. 11, p. 1084-1092, 2009. Available at: <http:// apsjournals.apsnet.org/doi/10.1094/PDIS-93-11-1084>. Accessed on: 28 Apr. 2017.

7. R Core Team. R: A language and environment for statistical computing. Viena; 2015. Available at: $<$ http://www.r-project.org/>. Accessed on: 25 Jul. 2016.

8. Zanotti, J.; Gouvea, A. de; Pizzatto, M.; Maaro, S. M.; Possenti, J. C.; Venturini, T.; Api, I. Indução de resistência a oídio (Microsphaera diffusa) em soja (Glycine $\max$ ( L .) Merr .) mediada por entomopatógenos. In: Congresso Brasileiro de Agroecologia, 6., 2009, Curitiba. Anais. Curitiba, PR: Associação Brasileira de Agroecologia, 2009. p. 339-343.

9. Zenebon, O.; Pascuet, N. S.; Tiglea, P. Métodos físico-químicos para análise de alimentos. $4^{\text {th }}$ ed. São Paulo: Instituto Adolfo Lutz; 2008. 1020 p. Available at: <http://www.ial.sp.gov.br/resources/editorinplace/ ial/2016_3_19/analisedealimentosial_2008.pdf?attach=true >. Accessed on: 28 Apr. 2017. 